部位を十分切除し，心室中隔の左室側にテフロンパッチ をあて穿孔部を閉鎖する，2）IABP による後負荷の減 少がある。一方, 心機能の状態からみた手術時期は, シ ョック症例では IABP 開始後 24 時間以内に手術が,必要 である．重症心不全例では IABP の効果は一過性であり， 数日後心不全は堌悪する. 循環動態の改善がみられない
ものは梗塞発症後 2 週間以内に手術すべきである.

僧帽弁閉鎖不全では心室中隔穿孔例と同様にショック 症例では緊急手術を行う．重症心不全症例では多藏器の 障害がおこる前に早期手術が望をれる.

文 献 1) Daggett, W. M.: World. J. Surg. $2: 753,1978$.

\title{
AIV-18 僧帽弁閉鎖不全を合併した心室瘤に対する外科治療
}

\begin{tabular}{|c|c|c|c|c|c|c|c|}
\hline 湯浅 & 浩 & 大井 & 勉 & 森本 & 保 & 坂井 & $\begin{array}{c}\text { 心缄 } \\
\text { 隆 }\end{array}$ \\
\hline 庄村 & 赤裸 & 山崎 & 順彦 & 千種 & 弘章 & 草川 & 実 \\
\hline 増田 & 浩一* & 水谷 & $\begin{array}{l}\text { 哲夫* } \\
\text { 木下 }\end{array}$ & $\begin{array}{l}\text { 新実 } \\
\text { 肇彦** }\end{array}$ & 藤昭* & 藤井 & 英樹** \\
\hline
\end{tabular}

昭和 48 年以降, 192 例の虚血性心疾患に手術を行い, このらち心室瘤に 対する手術は 30 例である。，心室瘤 30 例中手術近接死 1 例， $3 \%$ と汪活満足すべき成績で ある. しかし, 生存例 29 例の術後臨床症状は, 僧帽弁 閉鎖不全（以下 MR）を合併しない 21 例中 18 例, $85.7 \%$ は NYHA I 度に改善されたのに対し, MR(十) 群 8 例では, 術後 MR の消失した 5 例, $62.5 \%$ は NY HA I 度に改善したが，術後 1 ないし 3 度の MR 残存 を認める 3 例， $37.5 \%$ では NYHA II 度に止まってい る.
行動態を検討し報告する.

対象は, 男 7 例, 女 1 例の計 8 例で, 年令は最低 31 才, 最高 64 才, 前壁, 前側壁あるいは前壁中隔に梗塞 を認めるもの 7 例, 後壁梗塞を認めるもの 2 例である. $75 \%$ 以上の狭窄を認める冠動脈病変は，7 例で前下行 枝に，3例で回旋枝に，3 例に右冠動脈に認めたが，症 例 8 は冠動脈狭窄を認めない冠動脈孌縮による心䇗梗塞 であった．MR の程度と術前臨床症状との関係は，MR の高度な症例では NYHA IIIないしIV度であるが，MR が軽度の症例でも NYHA IV度のものもあり, MR の程 度と臨床症状は必ずしも一致しなかった。これは, 本症

表 1 僧帽弁閉鎖不全を合併した心室瘤症例

\begin{tabular}{|c|c|c|c|c|c|c|c|c|c|}
\hline 症 & 例・年 & 令・性 & & 梗塞部位 & 左軸偏位 & 不整脈 & 冠状動哌病変 & NYHA & $\begin{array}{l}\text { MR } \\
\text { 程 度 }\end{array}$ \\
\hline 1. & & 52 & 男 & 前 側 壁 & $(+)$ & $(-)$ & LAD $90 \%$ & III & 2 \\
\hline 2. & & 31 & 男 & $\begin{cases}\text { 前 } & \text { 譬 } \\
\text { 壁 }\end{cases}$ & $(+)$ & $(+)$ & $\begin{cases}\text { LAD } & 100 \% \\
\mathrm{CX} & 100 \%\end{cases}$ & IV & 3 \\
\hline 3. & & 48 & 男 & 前 壁 & $(-)$ & $(+)$ & $\begin{cases}\text { LAD } & 90 \% \\
\mathrm{CX} & 90 \%\end{cases}$ & II & 1 \\
\hline 4. & & 64 & 男 & 前壁 & $(-)$ & $(-)$ & $\left\{\begin{array}{l}\text { RCA } 100 \% \\
\text { LAD } 100 \% \\
\text { CX } 50 \%\end{array}\right.$ & IV & 2 \\
\hline 5. & & 58 & 男 & 前壁中隔 & $(+)$ & $(-)$ & $\begin{cases}\text { RCA } & 75 \% \\
\text { LAD } & 90 \% \\
\text { CX } & 75 \%\end{cases}$ & III & 3 \\
\hline 6. & & 57 & 男 & 前壁中隔 & $(+)$ & (H) & $\begin{cases}\text { RCA } & 75 \% \\
\text { LAD } & 90 \%\end{cases}$ & III & 2 \\
\hline 7. & & 63 & 女 & 前壁中隔 & $(+)$ & $(-)$ & LAD $90 \%$ & IV & 1 \\
\hline 8. & & 64 & 男 & 後 壁 & $(-)$ & $(-)$ & 冠動脈攣縮 & III & 4 \\
\hline
\end{tabular}


表 2 手術所見および術式

\begin{tabular}{|c|c|c|c|c|c|}
\hline 症 & 例 & 心空瘤の大きさ & 血栓 & 乳頭筋の梗塞 & 式 \\
\hline 1. & & $5 \times 7 \mathrm{~cm}$ & $(-)$ & $(+)$ & 瘤切除術 \\
\hline 2. & & $7 \times 7 \mathrm{~cm}$ & $(-)$ & $(H)$ & 瘤切除術十僧帽弁輪形成術 \\
\hline 3. & & $3 \times 4 \mathrm{~cm}$ & $(-)$ & $(-)$ & 瘤切除術＋A-C バイパス術 (LAD) \\
\hline 4. & & $4 \times 8 \mathrm{~cm}$ & $(-)$ & $( \pm)$ & 瘤切除術＋A-C バイパス術 (RCA) \\
\hline 5. & & $4 \times 5 \mathrm{~cm}$ & $(-)$ & $( \pm)$ & 瘤切除術+A-C バイパス術 (LAD) \\
\hline 6. & & $5 \times 10 \mathrm{~cm}$ & $(-)$ & $(+)$ & 瘤切除術 $+\mathrm{A}-\mathrm{C}$ バイパス術 (RCA) \\
\hline 7. & & $6 \times 7 \mathrm{~cm}$ & $(+)$ & $(-)$ & 瘤切除術+A-C バイパス術 (LAD) \\
\hline 8. & & $5 \times 5 \mathrm{~cm}$ & $(-)$ & $(+)$ & 瘤切除術＋僧帽弁置換術 \\
\hline
\end{tabular}
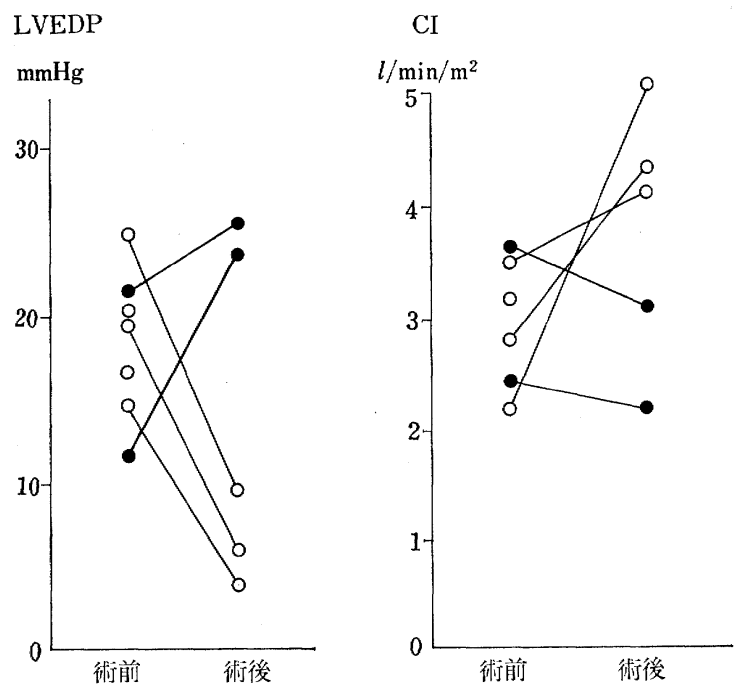

LVEDVI

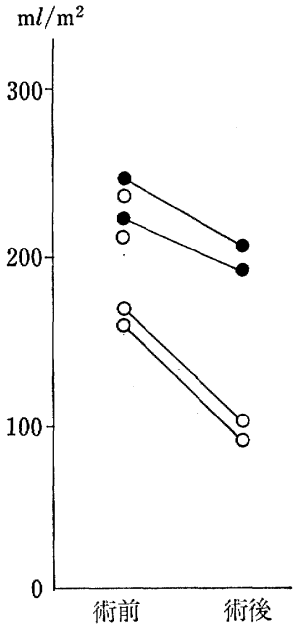

図 1 血行動態の推移

印は MR 残存例)

では MR の他に心筋障害または心室嵧の大きさが臨休 症状に関与しているためである（表 1 ）.

手術所見では, 前乳頭筋附着部の梗塞様病変は 6 例で みられ，とくに症例 2 および 8 では，梗塞による瘢痕化 が認められた。症例 1 には瘤切除術のみを行い，症例 3 から症例 7 には $\mathrm{AC}$ バイパス術を加え, 症例 2 和よび 8 には，弁輪形成術または弁置換術を加えた，術後は症例 $1 ， 3 ， 6 ， 7 ， 8$ の 例で MR を認めず，䧄床症状 も改善したが，症例 $2 ， 4 ， 5$ の 3 症例で 1 ないし 3 度 の MR がみられている(表 2)，術後血行動態は，術 後 MR (一) 例では, LVEDP は平均 $20 \mathrm{mmHg}$ から 術後平均 $7 \mathrm{mmHg}$ 之低下し, CI は平均 $2.95 \mathrm{l} / \mathrm{min} /$ $\mathrm{m}^{2}$ から術後平均 $4.5 l / \mathrm{min} / \mathrm{m}^{2}$ と増加し, LVEDVI む $181 \mathrm{~m} l / \mathrm{m}^{2}$ から術後 $105 \mathrm{~m} l / \mathrm{m}^{2}$ 一減少している. 術後 MR（十）例では，LVEDP，CI の改善がみられず，L
VEDVI も高値を示している (図 1). さらに, abnormal contracting segment の割合 (以下\% ACS) と LV EDVI との関係では, 術後 MR (一) 群では, \% ACS および LVEDVI ともに術後には低下しているが，MR （十）群では\%ACS は術後低下を認め，心室瘤切除術の 効果はあったものの，MR 残存のため依然として LVE DVI は高值に止まっている. また，術前後の UCG の 検討でも, 術後 MR (一) 群では, 左房径, 左室径はと もに減少し, 左室後壁運動も $28 \mathrm{~mm} / \mathrm{sec}$ から術後平均 $44 \mathrm{~mm} / \mathrm{sec}$ と改善されている. しかし, 術後 MR (十) 群では，UCG 所見での改善は認められない.

\section{結語}

1. 心室溜 30 例に手術を行い, 手術近接死 1 例, 3 \%であった。 
2. MR (-) 群 21 例中 18 例, $85.7 \%$ 注術後 $\mathrm{N}$ ている.

YHA I 度に改善されたが, MR (十) 群 8 例中術後 MR の残存した 3 例， $37.5 \%$ は NYHA II 度に止まっ

3. MR (十) 群では術後 MR を残さないことが必 要である.

\title{
AIV-19 左心室瘤33例に対する外科治療の検討
}

\author{
小倉記念病院 心臓血管外科 \\ 花田 正治 伴 敏彦 曽根田純一 平田 和男 \\ 西村 和修 武内 俊史 本井 智己
}

近年虚血性心疾患の增加とともに, 心筇梗塞の合併症 として左心室瘤への外科手術も積極的に施行されるよう になった. 私たちの施設では過去 7 年間に 33 例の左心 室瘤切除術を施行した。この 33 例の手術適応・合併手 術予後について検討を加光報告する。

\section{対象および手術適応（表 1)}

過去 7 年間に 33 例の左心室瘤切除術を施行した. 前 壁 32 例下壁 1 例であった男 26 例,女 7 例. 年令 $32 \sim$ 71 才 (平均 55 才), 心係数 $2.91 \pm 0.64 l / \mathrm{min} / \mathrm{m}^{2}$, 左室 抎張終期圧 $15 \pm 8 \mathrm{mmHg}$, 冠動脈病変として, 1 枝病変 9 例, 2 枝病変 17 例, 3 枝病変 7 例. 合併症として, 僧帽弁閉鎖不全症 2 例，心室中隔穿孔 1 例であった。手

表 1 対象および手術適応

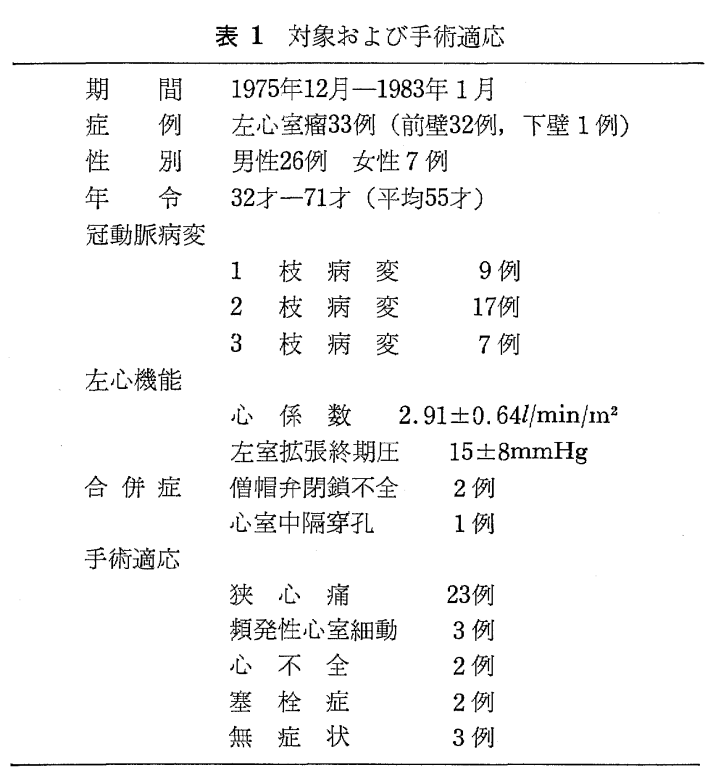

術適応としては，狭心痛によるものが 23 例で, このう ち心室性頻拍症 1 例, 多発性期外収縮 2 例, 僧帽弁閉鎖 不全症 1 例を認めた．頻発性心室細動に上るものが 3 例 で全例, 頻回の徐細動を要し, 緊急手術を施行した. ち 2 例は急性期手術であった，心不全によるものが 2 例 で，1例は僧帽弁閉鎖不全症を，1 例は心室中隔穿孔を 合併していた．塞栓症によるものが 2 例で，他 3 例は無 症状であった。

\section{合併手術（表 2）}

瘤切除術のみは 14 例であった. AC バイパス術を施 行したるのは 17 例で，1本バイパス 8 例， 2 本バイパ ス 8 例, 3 本バイパス 1 例であった。僧帽弁閉鎖不全症
表 2 合 併手術

\begin{tabular}{|c|c|}
\hline 左心瘤切除術のみ & 14 \\
\hline AC バイパス術 & 17 \\
\hline 1 本 & 8 \\
\hline 2 本 & $8^{*}$ \\
\hline 3 本 & $1^{*}$ \\
\hline 僧帽弁置換術 & $2^{*}$ \\
\hline 心室中隔穿孔根治術 & 1 \\
\hline
\end{tabular}

*2本バイパス及び僧帽弁置換術施行例 1 例を含む

\begin{tabular}{|c|c|}
\hline 病 院 死 & 0 \\
\hline 遠 隔 死 & 1 (突然死) \\
\hline 狭 心 痛 & 1 \\
\hline 心室性期外収縮 & 1 \\
\hline 心 不 全 & 0 \\
\hline 塞 栓 症 & 0 \\
\hline 無 症 状 & 30 \\
\hline
\end{tabular}

